\title{
The Degree of Applying Good Governance in Tafila Technical University from its Faculties and Administrators Views
}

\author{
Dr. Sulaiman Hajaia \\ Department t of Educational Psychology \\ Faculty of Educational Sciences \\ Tafila Technical University, 66110, P.O. Box 179, Tafila, Jordan \\ Tel: 96-279-832-2170_E-mail: sulimanhajaia@yahoo.com.
}

Received: June 4, 2017 Accepted: Oct. 26, 2017 Published: November 1, 2017

doi:10.5296/jse.v7i4.11758 URL: https://doi.org/10.5296/jse.v7i4.11758

\begin{abstract}
The study aimed to assess the degree of applying good governance in Tafila Technical University. To accomplish the study objectives; the researcher choose randomly 100 faculties and 102 administrators from Tafila Technical University. A questionnaire was used to collect data. The results indicated that the governance practices were mid, and there is no statistically significant difference $(\alpha=0.05)$ in the degree of applying governance and its domains at Tafila Technical University attributed to Job and experience.
\end{abstract}

Keywords: Governance, Faculties, Administrators, University. 


\section{Introduction}

Competence and efficacy are considered the only means for achieving the goals of establishments, organizing and investigating the human and substances resources which lead to success and improve their performance outcomes. The educational or public administration is considered as the main element for progress and prosperity.

For achieving the competence and efficacy domains in educational system, there must be activating for the concept of good governance which includes good management for all resources, and to ensure the performance quality through participation and transparency, in addition to reserving the rights of all workers. Governance is a new system based on systems and criteria which control the work and improve the outcomes. (Castro, 2012).

For achieving the targeted goals through good governance with less time, effort, and finance, this requires administrative procedures which prevent deviation of establishments and ensure good and prosperous behaviors. Tsiford \& Elftheriadou (2007) added that governance participates in giving opportunities for administrators in designing policy, leading to positive outcomes, and increasing productivity. Good Governance is considered as an important element of administration on through its role in decisions making and the procedures of evaluating and investigating, and the efficacy of decisions to make sure of transparency and accountability of an establishment based on legislation reference which organizes the work. (Saleh,2010)

There are many goals for governance that could be accomplished by participating effectively in preventing deviation and trickery through control and observation to procedures guarantee fairness and integrity. In addition to that, to limit authority independence and performance control. (Shaban,2013).

Governance is considered the only way as protection against crises. and risk, in addition to accomplishing transparency, and limiting the authority independence except for public interests and the commitment with rules and laws (Assyed, 2006).

Nasir Aldein, (2012) indicated that applying the governance leads to:

- $\quad$ Right decision making for reserving incomes.

- Ideal use for financial and human resources.

- Appreciating the value of the establishment and its competitive ability.

- Discipline, responsibility, and social fairness.

- Accomplishing the goals of the establishment.

He also added that, applying the governance in universities accomplishes the administration and leadership quality, performance, and the quality of processes and outcomes.

(Al kayed, 2003) showed that, good governance is characterized with:

- Transparency: which means, taking decisions based on limited rules, and the information 
should be clear and easy to be understood.

- Participation: which means, the participation of all targeted parties in setting administrative rules and foundations.

- Accountability: which means, questioning all parties when taking a decision.

- Efficacy and competence: which means, the best way of investing the financial and human resources for achieving the goals of the establishment.

- Law judgment: which means, applying the law without bias on all parties when taking a decision. The good governance aims to find the laws and systems that accomplish university leadership democracy and extends the base of participation when making and taking decisions. It also accomplishes administrative transparency and participates in finding a positive university climate for all workers which ultimately leads to efficacy and increases university competence. (Alzahrani, 2012). Aloraini (2014) conducted a study aimed to recognize the reality of applying governance from faculties and administrators staff in AlEmam Mohammad Bin Saud University from their views. The sample consisted of (650) individuals from the two staffs. The results indicated that the reality of applying governance came with mid degree. The results also showed that there are significant differences attributed to the variable of experience in favor of (11-20) year experience. The transparency domain came in the first rank, followed by accountability domain, and the participation domain came in the last rank. Mok (2010) conducted a study aimed at finding out the extent of applying good governance in Singapore and Malaysian Universities through evaluating the administrative governance by academic staff and its effect in changes that took place in the university life. Presented reports and analyses through his interviews in the campus during (2007-2009). The results showed that there are no significant differences in applying governance in Singapore and Malaysian universities by academics for assessing the administrative governance and its effect on changes that took place in university life. The results indicated that the administration of the university offered some academic freedom, but most academics did not feel with big differences in reformations after applying governance in their universities. In addition to that, most academics are still exposed to stress in their universities, and they see that the state is able to monitor the universities.

Alzahrani $(1331 \mathrm{H})$ conducted a study aimed to applying the good governance in private universities in Saudi Arabia and its relations with job satisfaction and organizational loyalty for faculties. The sample consists of (300) faculties. The results showed that private universities in Saudi Arabia apply governance in a high degree.

Alshonnak (2009) conducted a study aimed to recognize the concept of good governance and the degree of practicing it in Jordanian private universities. The sample consists of (501) individuals, (63) of them are members in the universities councils, (258) are faculties, and (180) are administrators. The results indicated that the level of understanding by the academic administration for governance domains came with a high degree. They also showed that there are significant differences between academic staff and administrative staff in favor of academic staff according to transparency criterion. 
Nasir Aldeen (2012) conducted a study aimed to recognize the reality of applying good governance in the Middle East University in Jordan from faculties and administrators views. The sample consisted of (64) faculties and (49) administrators. The results showed that the level of applying governance was high; there are also significant difference in favor of faculties, and in favor of more than two-year experience.

Mungiu and Dusu (2011) conducted a study aimed to assess the Roman State Universities, (43) universities were assessed based on original methodology for academic and administrative integrity, democratic rule, and proper finance for one academic year. The results indicated that there are systematic problems in university life and the work performance attributed to the failure of constructing accountability systems on the level of the university after applying decentralization in university education for competition in order to improve a university reform for its practices.

Deboer, Huissman, and sheyth (2010) conducted a study aimed to discuss the governance situations in Netherland, Austria, and united Kingdom Universities. It differentiated between supervising councils regarding accountability, questioning, and transparency. The study concluded that the modern elements in reforming European higher education are forming new structures for the governance of universities taking into account that, the supervising councils are part of reforming processes. Despite the importance of these councils, few members of them know their actual work. In addition to that, development will not take place unless there must be application for governance and its principles accurately, and activating the role of internal and external control.

Kpis (2009) conducted a study aimed to recognize the essential indicators of performance regarding governance in Malaysia universities. The researcher used qualitative and quantitative methodology for data collection about the indicators of governance performance in these universities. The sample consisted of (72) deans, (128) vice deans, and (276) professors. The results showed that there are some leadership skills as constructing good personal relations, and offer administrative communication. The factors of governance success are: trust, honesty, accountability, and transparency.

Wang (2010) conducted a study aimed at recognizing the self judgement of a university and the extent of the state control in higher education, through policy planning for higher education, through studying rules, organizational departments, and respondents' views about the tool of the study. The result indicated that the application of governance through its three principles (transparency, accountability, and participation) offers creativity and ability in developing the university and the state control that could be reflected on the outcomes of a university clearly.

\section{Statement of the problem}

Governance is considered as one of the basic principle in reforming higher education, and one of the administrative income for accomplishing the goals of a university and its vision.

This study came to recognize the degree of applying the principles of good governance in Tafila Technical University through answering the following questions: 


\section{Macrothink}

- What is the degree of applying good governance from the administrative and faculties' views in TTU?

- Are there statistically significant differences at $(\alpha=0.05)$ attributed to the variables of experience and job?

\section{Study importance}

The results of the study could be beneficial for the leadership of TTU to recognize the reality and the obstacles of applying good governance and how to develop it.

\section{Method}

\subsection{Design}

The study adopted the descriptive design because it is a suitable method for this study purposes.

\subsection{Population}

The population of the study consisted of (200) faculties and (204)administrators during the $2^{\text {nd }}$ semester of the academic year $2016 / 2017$ as table 1 shows.

Table 1. Study population

\begin{tabular}{lc}
\hline Job & No. \\
\hline faculties & 200 \\
administrators & 204 \\
Total & 404 \\
\hline
\end{tabular}

\subsection{Sample}

The sample was chosen by stratified random method, as table 2 .shows:

Table 2. Study Sample

\begin{tabular}{llll}
\hline Job & Less than 6 year experience & More than 6 year experience & Total \\
\hline Faculty & 43 & 57 & 100 \\
Administrator & 50 & 52 & 102 \\
Total & 93 & 109 & 202 \\
\hline
\end{tabular}




\subsection{Instrument}

The researcher developed a tool after reviewing the related literature. The tool consisted of three domains: transparency which included (11 items), accountability which included (10 items), and participation which included (8 items). Likert five level scale was adopted for grading the items of the tool.

\subsection{Validity}

The tool was given to a jury of referees including specialized experts in educational administration, public administration, and assessment and evaluation specialists at TTU. The researcher took into account the notes of the referees, so it was modified to become (24) items in its final copy.

\subsection{Reliability}

To make sure that the tool is reliable, test-retest, and internal consistency were computed through distributing the tool to a pilot sample of (211) faculties and administrators chosen randomly from the population and out of the sample of the study as table 3 indicates:

Table 3. Reliability coefficient

\begin{tabular}{lll}
\hline Domain & Test-retest & Internal consistency \\
\hline Transparency & 0.89 & 0.87 \\
Accountability & 0.88 & 0.81 \\
Participation & 0.84 & 0.79 \\
Total & 0.91 & 0.90 \\
\hline
\end{tabular}

The figures in table 3 show that the total average for the tool as a whole was 0-91 for test-retest and 0.92 for Chronbach Alpha which means that the tool is reliable.

\section{Statistical procedure}

For answering question no.1, means and standard deviations were computed, whereas, MANOVA was used for answering question no.2

\section{Results}

In order to interpret the means of the study tool; the following criteria were used:

$$
-1-2.33 \text { low }
$$

- 2.34-3.67 mid

- 3.68-55 high 
6.1 Results for question1

- To answer Q1 which states: what is the degree of applying good governance from the administrative and faculties staff views in TTU? Means and standard deviations for governance were computed as table 4 represents :

Table 4. Means, standard deviations, rank, for the levels of governance

\begin{tabular}{lllll}
\hline Domain & Mean & standard deviations & Rank & Mean description \\
\hline Accountability & 3.43 & 0.40 & 1 & mid \\
Participation & 3.37 & 0.20 & 2 & mid \\
Transparency & 3.19 & 0.29 & 3 & mid \\
Total & 3.33 & 0.22 & & \\
\hline
\end{tabular}

Table 4 showed that the governance domains were mid, this could be due to the way of handling administrative work at TTU which depends upon routine work that is controlled by the university regulations. This result is similar to the findings of Aloraini (2014), but it differs from Alzahrani (2010) and Nasir Aldeen (2012).

Means and standard deviations for the items of accountability domain were computed as table 5 shows: 
Table 5. Means and standard deviations for the items of accountability domain

\begin{tabular}{|c|c|c|c|c|c|}
\hline $\begin{array}{l}\text { Item } \\
\text { No. }\end{array}$ & item & mean & $\begin{array}{l}\text { standard } \\
\text { deviation }\end{array}$ & rank & $\begin{array}{l}\text { Mean } \\
\text { description }\end{array}$ \\
\hline 1 & $\begin{array}{l}\text { All regulations and instructions were applied } \\
\text { at the university. }\end{array}$ & 3.70 & 0.58 & 1 & High \\
\hline 5 & $\begin{array}{l}\text { The university has clear norms to evaluate } \\
\text { the staff. }\end{array}$ & 3.49 & 1.11 & 2 & Mid \\
\hline 3 & $\begin{array}{l}\text { The university applies individual and group } \\
\text { accountability system. }\end{array}$ & 3.38 & 0.79 & 3 & Mid \\
\hline 2 & $\begin{array}{l}\text { College councils were exposed to } \\
\text { accountability about their performance. }\end{array}$ & 3.28 & 0.72 & 4 & Mid \\
\hline 4 & $\begin{array}{l}\text { The university has clear instructions for } \\
\text { departments, colleges, and councils. }\end{array}$ & 3.13 & 1.14 & 5 & Mid \\
\hline 6 & $\begin{array}{l}\text { The university has department for internal } \\
\text { monitoring. }\end{array}$ & 2.39 & 0.93 & 6 & Mid \\
\hline 8 & $\begin{array}{l}\text { Regulations were applied on all staff without } \\
\text { bias. }\end{array}$ & 2.91 & 1.07 & 7 & Mid \\
\hline 7 & $\begin{array}{l}\text { The university has external evaluation } \\
\text { system. }\end{array}$ & 2.72 & 1.07 & 8 & Mid \\
\hline
\end{tabular}

The results of this domain indicate that item 1 (All regulations and instructions were applied at the university) had the highest mean; this could be. explained by the fact that each department at the university had its own regulations which must be applied to perform the objectives of the department, and the department will be exposed to accountability if the regulations were not applied. Item 7( university has external evaluation system) had the lowest mean, this could be due to the evaluation process and the role of external evaluator. The results of this domain disagree with the findings of Nsir Adeen (2012).

Means and standard deviations for transparency domain were computed as table 6 shows: 
Table 6. Means and standard deviations for transparency domain

\begin{tabular}{|c|c|c|c|c|c|}
\hline $\begin{array}{l}\text { Item } \\
\text { No. }\end{array}$ & item & mean & $\begin{array}{l}\text { standard } \\
\text { deviation }\end{array}$ & rank & $\begin{array}{l}\text { Mean } \\
\text { description }\end{array}$ \\
\hline 14 & $\begin{array}{l}\text { Faculties and administrators participate in } \\
\text { constructing the university regulations. }\end{array}$ & 3.99 & 0.88 & 1 & high \\
\hline 12 & $\begin{array}{l}\text { Employees can express their opinions about } \\
\text { any issues regarding university }\end{array}$ & 3.70 & 1.25 & 2 & high \\
\hline 10 & $\begin{array}{l}\text { The university leadership uses democratic } \\
\text { method in decision making and decision } \\
\text { talking. }\end{array}$ & 3.41 & 1.28 & 3 & Mid \\
\hline 9 & $\begin{array}{l}\text { The university leadership involves community } \\
\text { representatives, faculties and employees in } \\
\text { constructing the university plans. }\end{array}$ & 3.35 & 0.93 & 4 & Mid \\
\hline 11 & $\begin{array}{l}\text { The university leadership modifies decisions } \\
\text { according to the employees' discussions. }\end{array}$ & 3.28 & 1.38 & 5 & Mid \\
\hline 13 & $\begin{array}{l}\text { The university leadership forms comities at the } \\
\text { university departments to encourage group } \\
\text { cooperative works. }\end{array}$ & 3.21 & 0.91 & 6 & Mid \\
\hline
\end{tabular}

Table 6 shows that item 14 (Faculties and administrators participate in constructing the university regulations) and item 12 (Employees can express their opinions about any issue regarding university) had highest means, this due to the university commitment in participating representatives from faculties and employees who are involved in conducting the university regulations in 
order to achieve the goals, especially that the university keeps up with all various changes and seeks for the best comperehensive quality. The rest of this domain items were mid, this could be resulted from spending too much time in constructing the infrastructure of the university. The results of this domain were similar to the results of Mgiu and Dusu (2011) and Deboer, Hulssman and Seytt (2010).

Means and standard deviations for sympathy domain were computed as table 7 shows:

Table 7. Means and standard deviations for transparency domain

\begin{tabular}{lrlll}
\hline $\begin{array}{l}\text { Item item } \\
\text { No. }\end{array}$ & mean $\begin{array}{l}\text { standard } \\
\text { deviation }\end{array}$ & $\begin{array}{l}\text { Mean } \\
\text { description }\end{array}$ \\
\hline
\end{tabular}

21 The university leadership has a data base for $\begin{array}{lllll}3.90 & 0.84 & 1 & \text { high }\end{array}$ the staff.

24 The university leadership has booklets for all $3.62 \quad 0.80 \quad 2 \quad 2 \quad$ high regulations.

$\begin{array}{llllll}20 & \text { The university leadership provides clear and } & 3.58 & 0.87 & 3 & \text { Mid }\end{array}$ transparent information to the others.

19 All staff members are responsible about $3.47 \quad 110 \quad 4 \quad$ Mid clarifying regulations to the others.

$\begin{array}{llllll}18 & \text { The university leadership applies regulations } & 3.43 & 0.88 & 5 & \text { Mid }\end{array}$ upon staff in a transparent way.

23 The university leadership applies $3.33 \quad 0.86 \quad 6 \quad 6 \quad$ Mid transparency in solving problems.

22 The university council provides information

$\begin{array}{llll}3.26 & 1.10 & 7 & \text { Mid }\end{array}$
about the analysis of internal and external university environment.

17 The university leadership announces the $2.85 \quad 1.10 \quad 8 \quad 8$ Mid criteria for selecting individuals for leadership and administrative jobs.

Table 7 indicates that item 21 (The university leadership has a data base for the staff) had the highest mean (3.90) this resulted from using the university website which contains all information about the university; which could be used as a source of information for marketing the university. Item 17 (The university leadership announces the criteria for selecting individuals for leadership and administrative jobs) had the lowest mean (2.85) this 
could be due to the hidden characteristics and the charisma of some individuals, so they were chosen to be leaders and these personal characteristics can not be announced.

The results of this domain disagree with the results of Alzhrani (2010) and Nasir Aldeen (2012)

\subsection{Results for question2}

Question 2 states that: Are there statistically significant differences at $(\alpha=0.05)$ attributed to the variables of experience and job? To answer it, MANOVA was used as tables 8 and 9 show:

Table 8. MANOVA for the effect of job title and experience upon governance.

\begin{tabular}{lllll}
\hline variable & Test & Test value & F & Sig \\
\hline job & Hotelling & 0.024 & 1.58 & 0.194 \\
experience & Hotelling & 0.001 & 0.075 & 0.98 \\
job* experience & Wilks' $\lambda$ & 0.998 & 0.153 & 0.928 \\
\hline
\end{tabular}

$*(\alpha=0.05)$ 
Table 9. MANOVA for the effect of job title and experience upon governance domains

\begin{tabular}{|l|l|l|l|l|l|l|}
\hline \multirow{2}{*}{ Source } & Domain & $\begin{array}{l}\text { Sum } \\
\text { squares }\end{array}$ & of & $\begin{array}{l}\text { Mean } \\
\text { Squares }\end{array}$ & F & Sig \\
\hline \multirow{3}{*}{ Job } & Transparency & 0.006 & 1 & 0.006 & 0.07 & 0.79 \\
\cline { 2 - 8 } & Participation & 0.11 & 1 & 0.11 & 2.63 & 0.106 \\
\cline { 2 - 8 } & Accountability & 0.237 & 1 & 0.237 & 1.45 & 0.229 \\
\hline \multirow{3}{*}{ Experience } & Transparency & 0.001 & 1 & 0.001 & 0014 & 0.907 \\
\cline { 2 - 8 } & Participation & 0.000 & 1 & 0.000 & 0.000 & 0.995 \\
\cline { 2 - 8 } & Accountability & 0.004 & 1 & 0.004 & 0.024 & 0.876 \\
\hline \multirow{2}{*}{ Experience } & Transparency & 0.007 & 1 & 0.007 & 0.084 & 0.772 \\
\cline { 2 - 8 } & Participation & 0.012 & 1 & 0.012 & 0.278 & 0.598 \\
\cline { 2 - 8 } & Accountability & 0.000 & 1 & 0.000 & 0.003 & 0.959 \\
\hline
\end{tabular}

$*(\alpha=0.05)$

According to tables 8 and 9 , there is no statistically significant differences $(\alpha=0.05)$ in the degree of applying governance and its domains at Tafila Technical university attributed to Job and experience. This finding may be due to the small number of the University staff, and the exposure of its staff to the same administrative and legal instructions, the study finding disagree with the results of Aloraini (2014), Alshonnak (2009) and Nasir Aldeen (2012)

\section{Recommendations}

According to the results of the study, the researcher recommends the following: university leadership has to implement governance principles, setting the legal and administrative frameworks for the governance and to oblige the different councils to implement them, and to spread the culture of governance among all employees at the university through awareness bulletins, seminars, workshops, and conferences.

\section{Conclusion}

Governance among faculties was mid and it was affected by faculty experience, and job.

\section{References}

Alkayed, Z. (2003). Governance: Issues and Applications. Egypt, Cairo: leaf lets of Arab Organization for development and administration. 
Aloraini, M. (2014). Reality of Applying good Governance from the views of administrators and faculties at Imam Mohammad Bin Saudi Islamic university. Specialized International Journal, 3(12), 115-147.

Alshonnak,R. (2009). The Governance concept and the degree of Practicing it in Jordanian Private Universities. Unpublished Ph.Dissertation, Jordan University, Amman, Jordan.

Alzahrani,Kh. (2010). The reality of applying good Governance in Saudi private universities and its relationship with Job satisfaction and systematic loyalty for its faculties. Unpublished Ph. D, Dissertation Um Alkura university, Mecca.

Assyed, E. (2006). Cumulative administration and Governance. Egypt, Alexanderia, Modern Arab office for publishing and distribution.

Castro, E. (2012). Higher education governance reform in practice matching institutional implementation practices and policies university and Knowledge. Society Journal, 9(2), 267-278.

Deboer, Harry, tluisman, Jeroen, \& Meister-scheytt. (2010). Supervision in modern. University Governance: Boards under scrutiny. Studies in Higher Education, 35(3), 17-333.

Kpis. (2009). Key performance indicators. For Governance of public university in Malaysia, Asian center for Research on university learning and Teaching.

Mungiy-pippidi, Alina. (2011). civil society and control of corruption "Assessing Governance of Romanian public university. International Journal of Educational Development, 31(5), 226-540.

Mok, Ka. (2010). When state centralism meets Neo-Liberalim: managing university Governance change in Singapore and Malaysia Higher Education: The international journal of Higher Education and Educational planning, 60(4), 419-440.

Nasir Aldeen,Y. (2012). Reality of Applying Governance in the Middle East University from its faculties and administrators Views. Arab Union Universities Journal, 62, 341-374.

Saleh M. G. (2010). The Extent of Applying the principle of Clarity and Transparence from Firms Governance principles in Amdawar Well LTD Firm. Unpublished M.A. thesis, Alnajah National University, Nablus, West Banr.

Sha'ban, A. (2013). Assessing the progress and good administration and Governance performance. Conference in public administration and Governance situation in Arab countries, choices or challenges and new demands. Held during q-11 December, Amman Jordanian.

Tsifora, E., \& Eleftheriadoy, P. (2007). Corporate Governance mechanisms and firm performance: Evidence from Greek manufacturing sector. Management of International Business and Economic system, 1(1), 181-211.

Wang, Li. (2010). Higher Education Governance and university Autonomy in china. Societies and Education, 8(4), 477-495. https://doi.org/10.1080/14767724.2010.537942 